\title{
The complex spreading pattern of Mediterranean Water off the Portuguese continental slope
}

\author{
WALTER ZENK* and LORENZ ARMI $\dagger$
}

(Received 12 August 1989; in revised form 6 December 1989; accepted 28 June 1990)

\begin{abstract}
Two stacked outflow cores of the Mediterranean Water undercurrent pass through a broad "gateway" between Cape St. Vincent and Gettysburg Bank entering the Iberian Basin. The upper core (depth $\sim 750 \mathrm{~m}, \sigma_{1}=31.85$ ) shows a strong tendency to follow the contours of the Portuguese continental rise. Yet, the lower core (depth $\sim 1250 \mathrm{~m}, \sigma_{1}=32.25$ ) primarily meanders west and northwestward forming large blobs of Mediterranean Water. The predominance of isolated Meddy structures embedded in a background field is reflected in a long-term current meter record from the deep Iberian Basin.
\end{abstract}

\section{INTRODUCTION}

THE GENERAL existence of the Mediterranean Water tongue as an outstanding component of the North Atlantic hydrography has been known since the CHALLENGER Expedition a century ago (BuCHAN, 1895). Defant (1955) suggested a radial spreading process based upon a constant balance of slow advection and turbulent mixing. He assumed a transposed point source just south of Cape St. Vincent, where a mixture of North Atlantic Central Water and of Gibraltar Outflow Water is no longer in contact with the bottom.

With the availability of continuously measuring CTD instruments at the end of the sixties, the hydrography of the Gulf of Cadiz attracted considerable attention. Howe (1982) summarized all these activities in a comprehensive review article. Based largely on the 1967 large scale survey by R.V. Jean Charcot, MadeLAIN (1970) concluded that the Gibraltar outflow, after turning sharply to the right south of Cadiz, is substantially influenced by the pronounced system of submarine channels, shelf canyons and seamounts. In the following years his chart of the discrete outflow channels became the basis for numerous expeditions.

Among the primary objectives of these campaigns were more detailed studies of spatial heterogeneity and temporal variability of the Gibraltar outflow. ZENK (1975a) estimated mixing rates between underlying Gibraltar Outflow Water and superimposed North Atlantic Central Water along a cascade through the Gulf of Cadiz. As a result he obtained a mean outflow volume of nearly $3 \times 10^{6} \mathrm{~m}^{3} \mathrm{~s}^{-1}(\mathrm{~Sv})$ at the point source. Later observations by HowE (1984), based upon 10-day current meter records on a slope section south of Cape St. Vincent indicated a much higher rate $(6.5 \mathrm{~Sv})$ of outflowing water. Further

\footnotetext{
*Institut für Meereskunde, Düsternbrooker Weg 20, 2300 Kiel, F.R.G.

†Scripps Institution of Oceanography, La Jolla, CA 92093, U.S.A.
} 
estimates of the important initial transport of Mediterranean Water volume were calculated by AmBar and Howe (1979b) and GrüNDLINGH (1981), the first based solely on geostrophy $(2.6 \mathrm{~Sv})$, the latter on a combined analysis of a single current meter mooring and a synoptic hydrographic section (4.3 Sv). In a recent attempt OCHOA and BRAY (1990) quantified seasonal changes of the Mediterranean Water outflow on the basis of repeated, narrowly spaced meridional sections in the eastern Gulf of Cadiz. These authors utilize inverse theory formalism to calculate outflows of 4.9, and 3.8 Sv for spring and fall 1986, at their westernmost section $\left(8^{\circ} \mathrm{W}\right)$. Characteristic inversions in vertical profiles of temperature and salinity (double maxima) often conserve mixing histories in form of two separate relative maxima (ZENK, 1975b; AMBAR and HowE, 1979a). Intermittent currents seen in current meter records and float trajectories from the Mediterranean Water level have been interpreted as meandering thermocline fronts such as the Azores Front (SIEDLER et al., 1985) or the Cape Verde Front (ZENK et al., 1990) or as migrating Meddies (ZENK and MÜlleR, 1988; ARMi et al., 1989).

In this paper we present data from a pilot study conducted in early 1989 on F.S. Meteor. These data have been merged with historical data, along with a selected CTD section taken aboard F.S. Poseidon in June 1989. In contrast to the recent contribution by KäSE et al. (1989) on the Mediterranean Water in the Iberian Basin, we mainly restrict ourselves to the easternmost part of the Iberian Basin where we expect the undercurrent of Mediterranean Water to be guided by the local topography. We synthesize and extend the available information on quasi-continuous outflow channels into the open Atlantic. Originally these veins were detected by Madelain $(1970,1976)$ in the inner Gulf of Cadiz and later extended towards its western outskirts south of Cape St. Vincent. We discuss the lateral Mediterranean Water distribution together with its stratification characteristics including geostrophic mass transport. The kinematic behaviour of the tongue background is illustrated by a multi-month current meter time series from the central Iberian Basin. Conclusive remarks are summarized in the last section which includes a perspective on future work with Lagrangian drifters in the Mediterranean Water tongue.

\section{CTD OBSERVATIONS}

In early January 1989, F.S. Meteor operated in the eastern North Atlantic along the Portuguese shelf and in the Iberian Basin. Although not in chronological order, we introduce several CTD sections (Fig. 1) arranged as discussed in the following paragraphs. The southern section $S$ connects Ampère Bank with Gettysburg Bank (Ormonde Bank), from where it continues to the shelf area just north of Cape St. Vincent. A middle section $M$ runs southwestward from Tejo Plateau into the deep Iberian Basin. The northern section $\mathrm{N}$, perpendicular to section $\mathrm{M}$, also leaves Tejo Plateau following a northwesterly course. Its northern end runs after a northward turn straight to Galicia Bank. This quasisynoptic data set is supplemented by a short section $F$, taken from the literature (MADELAIN, 1976). It is situated perpendicular to the shelf west of Cape Sines and another section P running towards the Douro mouth west of Porto.

In all sections, station spacing was reduced when approaching the continental rise, allowing us a well-resolved description of the Mediterranean Water cores. The complete CTD data set for sections $S, M$ and $N$ consists of 65 stations, nominally $25 \mathrm{~km}$ apart. The majority were taken down to 2050 dbars, deep enough to cover most of the water column influenced by Mediterranean Water. With the exception of the French section $F$, 


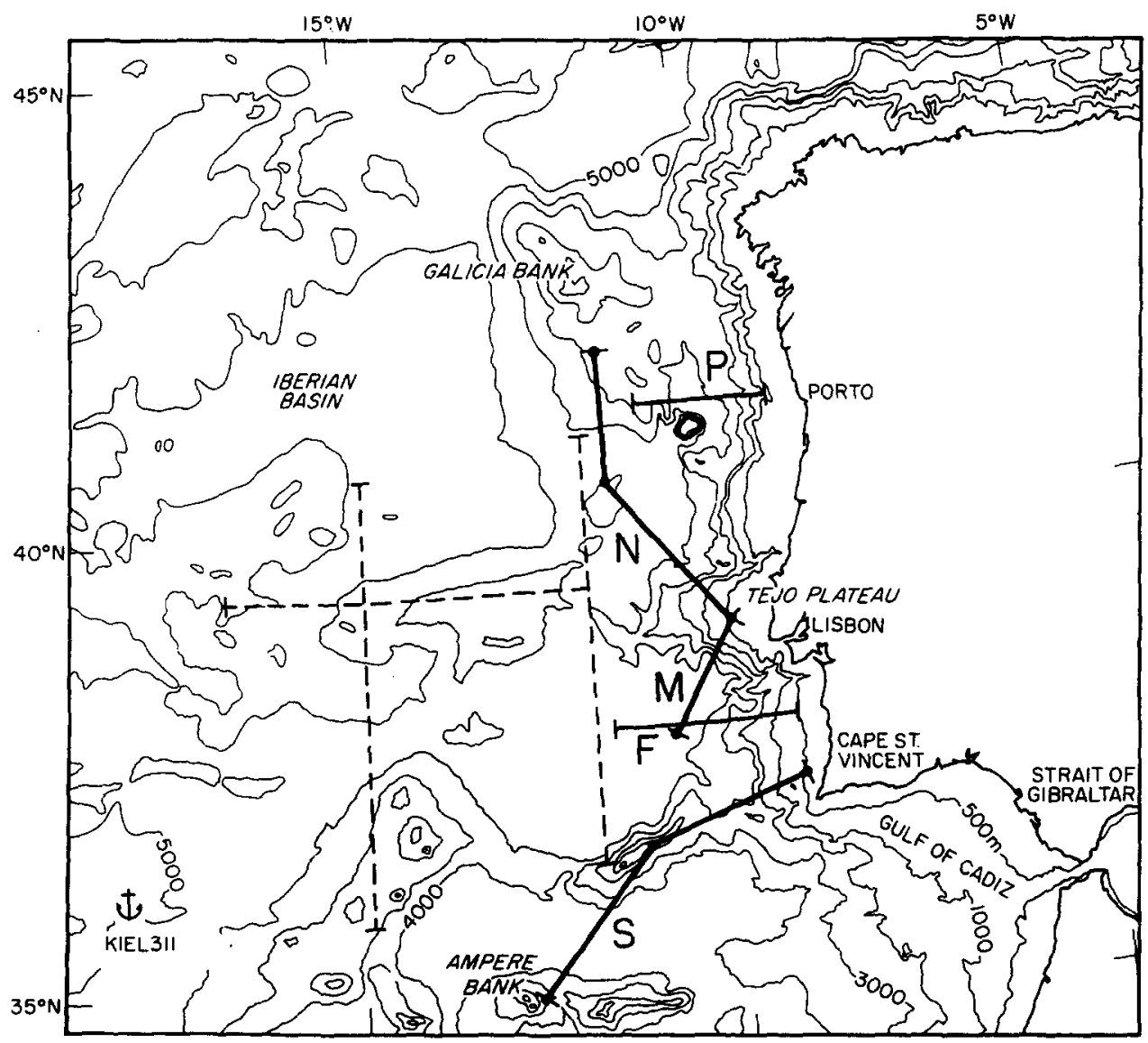

Fig. 1. Position of sections S, M, N and P occupied during Barlavento Expedition of F.S. Meteor in January 1989 and by F.S. Poseidon in Jure 1989 (P) together with supplementary sections from the literature ( $F$ by MADELAIN, 1976; unlabeled by KäSE et al., 1989). Sections primarily aimed at a determination of the spreading pattern of Mediterranean Water along the continental slope off Portugal. KIEL311 was a current meter mooring designed to monitor the flow in the outflow tongue.

instrumentation, data acquisition and reduction are identical with those described in KÄSE et al. (1989). For details the reader may refer to the extended cruise report (ZENK et al., 1989) of the Barlavento Expedition which included research areas reported here.

\section{Section S (south)}

Chronologically this CTD section (Fig. 2) starts just north of a canyon off Cape St. Vincent. It is subdivided into two broad gaps by the twin-peaked Gettysburg Bank (minimum depth approximately $40 \mathrm{~m}$ ). The southern end of section $\mathrm{S}$ is formed by the slope of the Ampere Seamount. The topographical division caused by the shallow Gettysburg Bank is clearly reflected in the distribution of hydrographic parameters. In the western part of the temperature section we recognize a low-gradient region between 600 
(a)

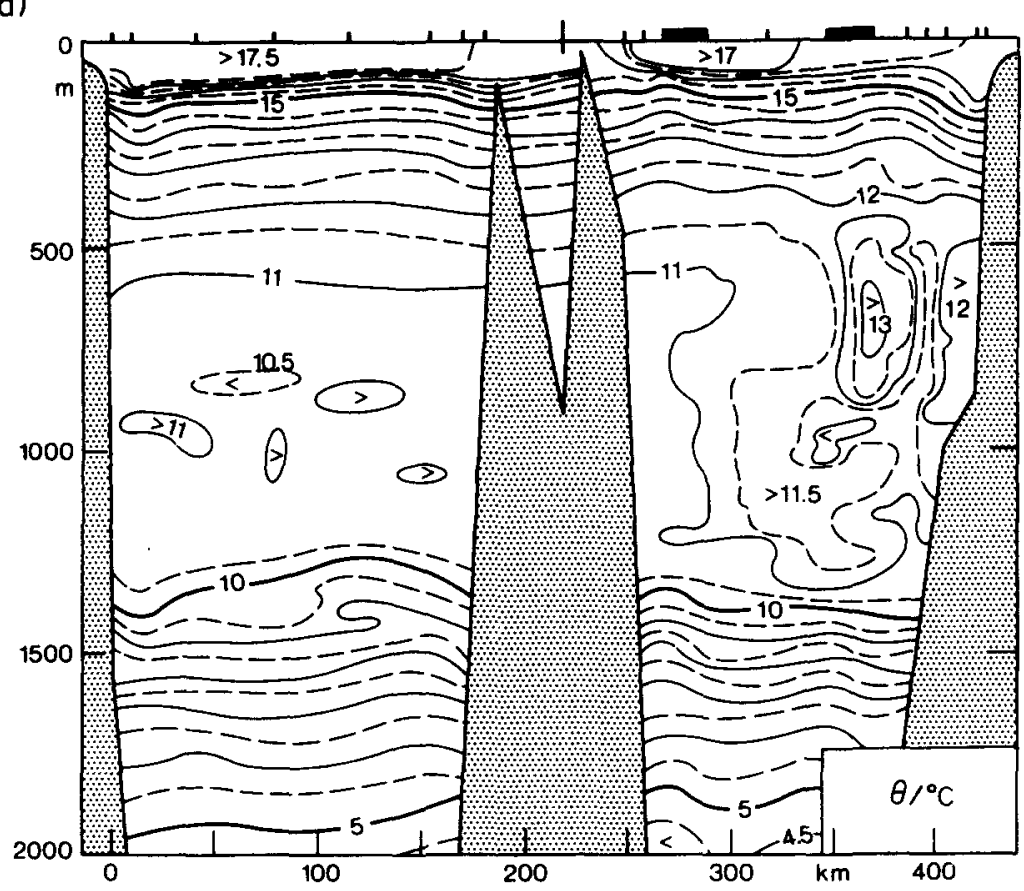

(b)

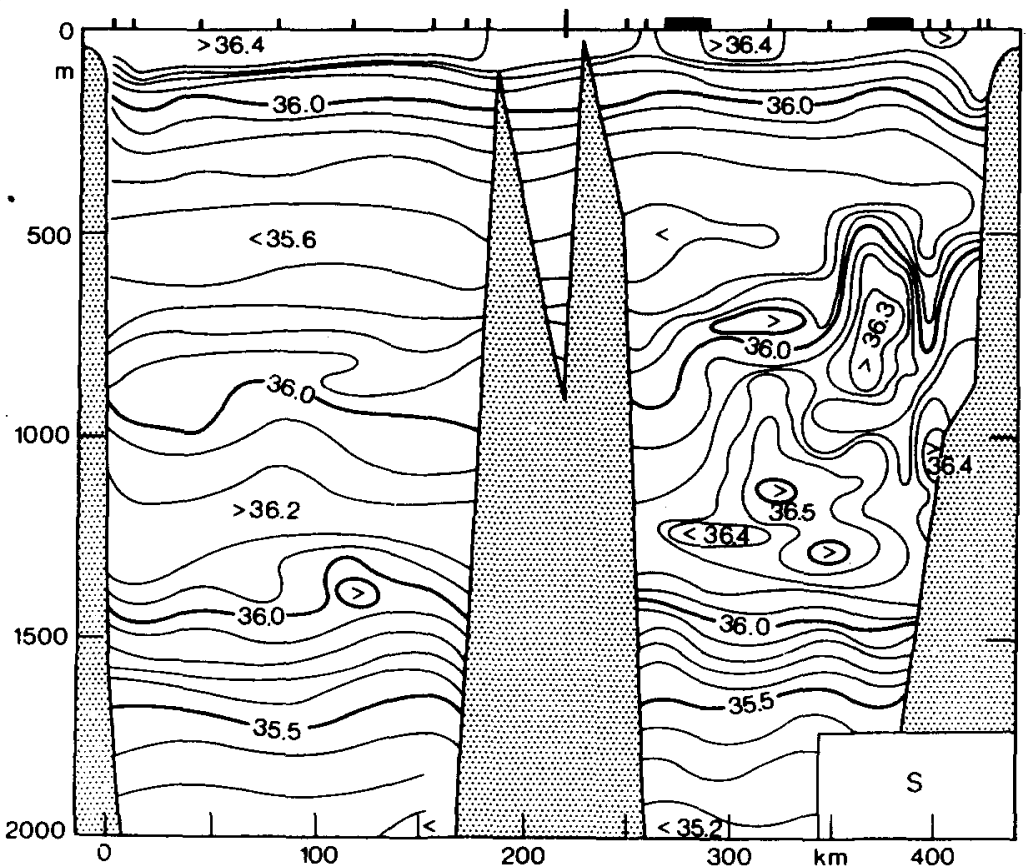


(c)

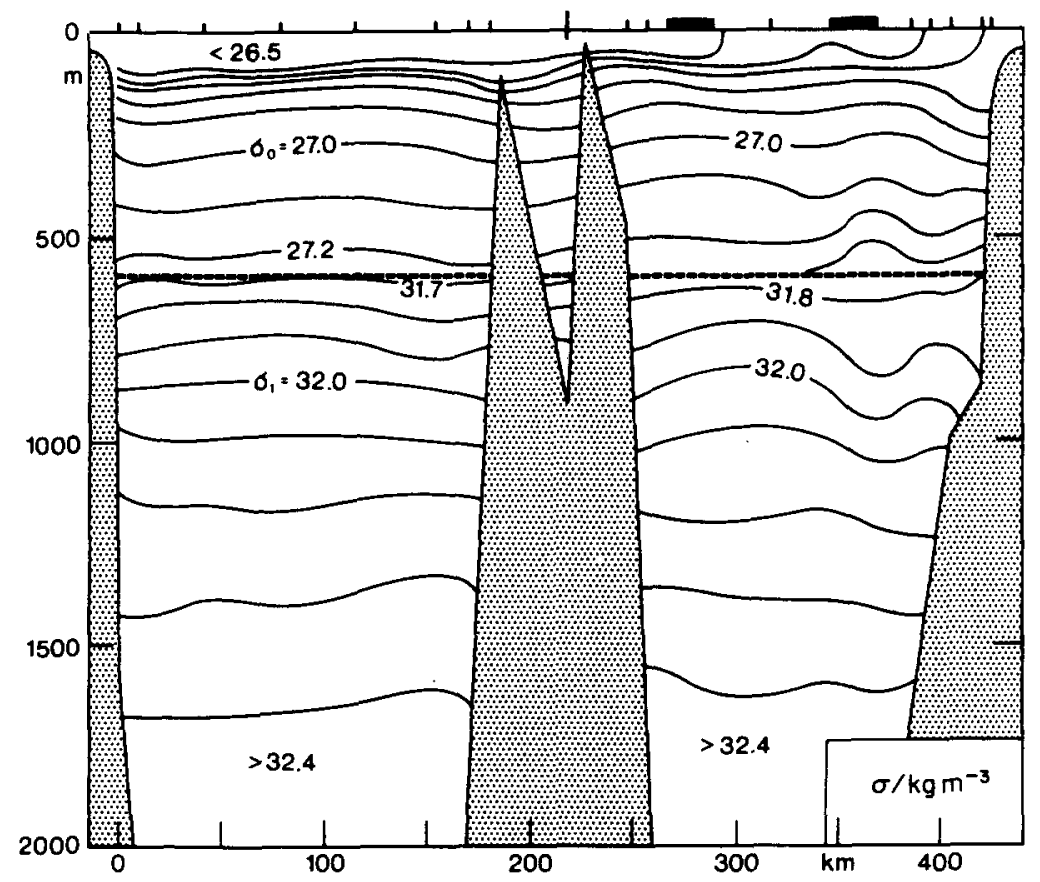

Fig. 2. CTD section $S$ connecting Ampère Seamount with double peaked Gettysburg Bank and Cape St. Vincent, southwestern edge of Iberian Peninsula. In respect to the warm salty Mediterranean outflow $(a, b)$ the section is divided into two parts, the western displaying the background tongue, the eastern showing core layers penetrating the open Iberian Basin. The density (c) at levels shallower than $600 \mathrm{dbar}$ is referenced to the surface $(\sigma)$, below $600 \mathrm{dbar}$ it is referred to 1000 $\operatorname{dbar}\left(\sigma_{1}\right)$.

and $1300 \mathrm{dbar}$, which continues onto the eastern flank of Gettysburg Bank. There we find a strong high temperature signal within the considered range of the Mediterranean Water outflow. The highest temperature exceeds $12.5^{\circ} \mathrm{C}$ between 500 and $950 \mathrm{dbar}$. There is also a second feature of higher midwater temperature $\left(11.5^{\circ} \mathrm{C}\right)$ in the $700-1300 \mathrm{dbar}$ range in the eastern part of the section.

As expected, most but not all of the temperature features are reproduced in the corresponding salinity section (Fig. $2 \mathrm{~b}$ ). In contrast to the low-gradient thermal stratification we encounter a clear salinity maximum $(>36.2)$ in the eastern gap. This layer is identical with Wüsr's (1936) classical core layer containing (by his definition) $80 \%$ of Mediterranean Water from the point source south of Cape St. Vincent.

We call the eastern gap between Gettysburg Bank and Cape St. Vincent a "gateway" for the Mediterranean Water into the deep Atlantic. We find two major cores, neither with any direct connection to the bottom. While the upper salinity core matches the strong temperature signal centered at $750 \mathrm{dbar}$, the main core at $1280 \mathrm{dbar}$ with salty patches as high as $\mathbf{3 6 . 5}$ is less visible in the temperature section. Both cores are separated horizontally by approximately $30 \mathrm{~km}$. A remainder of an intermediate high salinity feature is seen against the Portuguese continental slope. The tilt in the density field of section S (Fig. 2c) reflect high advective velocities associated with the core layers. We note that the upper 
(a)

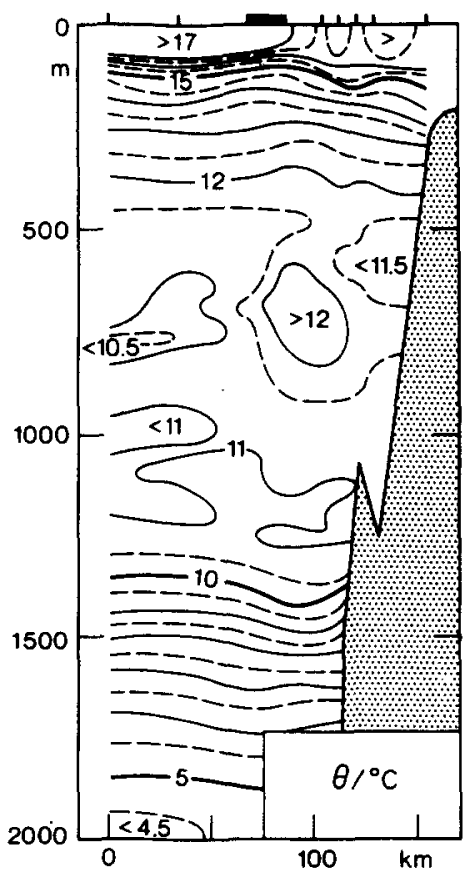

(b)

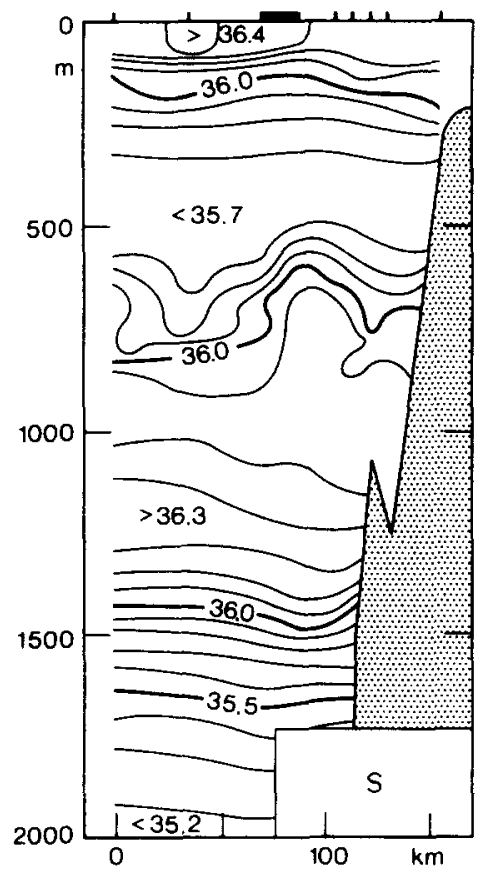

(c)

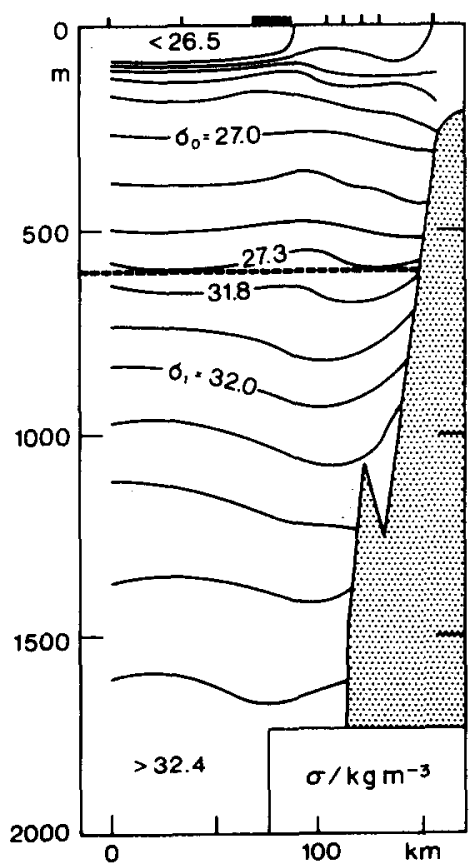

Fig. 3. Section $M$ southwest of Tejo Plateau. We recognize the warm upper core at $700 \mathrm{dbar}$ leaning against the continental slope. The main, i.e. deeper core at about $1250 \mathrm{dbar}$ resembles the background seen in the western portion of Fig. 2. Unfortunately, the turbulent deeper core from the middle part of the eastern portion of section $S$ was not captured by this section. (a) Potential temperature, (b) salinity, (c) densities $\sigma_{0}$ and $\sigma_{1}$. 
core is best represented by $\sigma_{1}=31.85$, whereas the lower (main) core can be identified by the $\sigma_{1}=32.25$ isopycnal.

\section{Sections $M$ (middle) and $F$ (French)}

Section M (Fig. 3) extends to the southwest from Tejo Plateau. Again, we focus on the Mediterranean Water level which represents the bottom of the main thermocline. Temperatures and their gradients are in the same range as seen in section $\mathbf{S}$ (Fig. 2a). The upper warm core $\left(>12.0^{\circ} \mathrm{C}\right)$ is closely confined to continental slope at approximately $750 \mathrm{dbar}$. There is a deeper salinity core layer $(>36.3)$ at $1200 \mathrm{dbar}$, spreading more horizontally, when compared with the more compact upper core. Both cores are situated at the same density levels (Fig. 3c) as seen in section S (Fig. 2c).

The different characteristics of both salinity cores drew our attention to a historical section F closely situated to section M (MADELAIN, 1976). A reproduction of section $F$ (Fig. 4) shows a pronounced gap in the highly saline core at $1200 \mathrm{~m}$ just at the same latitude where the Meteor section $M$ stops. Numerous related CTD sections from the area, found in MADELAIN (1976), all show a bifurcation tendency at the depth of the main salinity core south of Tejo Plateau. The inner branch follows the continental slope, while the outer tends to spread more to the northwest. This finding confirms our suspicion that Meteor section $\mathrm{M}$ is too short to cover the outbound salinity core seen in section $\mathrm{F}$.

\section{Section $N$ (north)}

The southeastern part of section $\mathrm{N}$ (Fig. 5) complements the near-slope part of section M. Again, we find two stacked Mediterranean Water cores at the same density levels $\left(\sigma_{1}=31.85\right.$ and 32.25). The upper core is best seen in the temperature section (Fig. 5a) $>11.5^{\circ} \mathrm{C}$ at $750 \mathrm{dbar}$, whereas the lower core is more easily visible in the salinity section (Fig. 5b), at a salinity $>36.3$ against the continental slope. We note that the highly saline core was found at $1400 \mathrm{dbar}$, at least $120 \mathrm{dbar}$ below the core layer encountered in sections $\mathrm{M}$ and $\mathrm{F}$ on the southern side of the plateau.

In the north-south leg of section $\mathrm{N}$ we see two obvious blobs of high salinity water $(>36.2)$ at shallower levels ( $1150 \mathrm{dbar})$. These features are also found in the thermal structure (Fig. 5a). Their density $\left(\sigma_{1}=31.15\right)$ lies between those of the upper and lower cores found near the continental slope north and south of Tejo Plateau. Section $N$ does not allow us to distinguish whether these features are interconnected by a meandering structure or whether they represent two isolated vortices, as discussed by KASE et al. (1989), for the area slightly further south.

\section{Section P (Poseidon)}

In order to trace the near-slope undercurrent northward we present the noncontemporary section P (Fig. 6) taken in connection with Poseidon cruise 159 in early June 1989. Not unexpectedly we find two distinct cores of Mediterranean Water water up against the continental slope. The maximum salinity $(>36.2)$ layer covers the pressure range from 1000-1400 dbar (Fig. 6b). It represents the classical main core. The core is best represented by the high temperature signal (Fig. 6a) at approximately $750 \mathrm{dbar}$ near the slope. Its corresponding density amounts $\sigma_{1}=31.85$ (Fig. 6c), i.e. the same level as seen in 
0 N

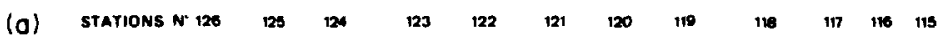

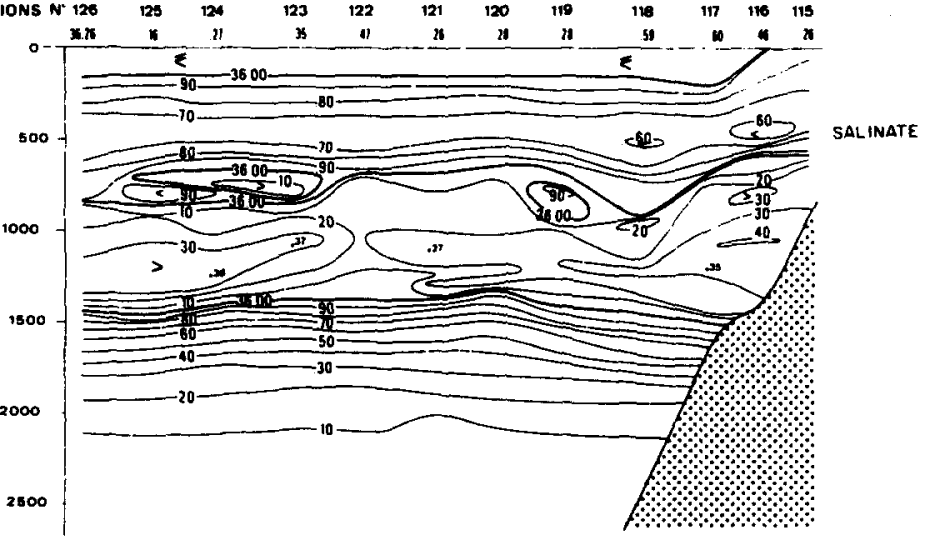

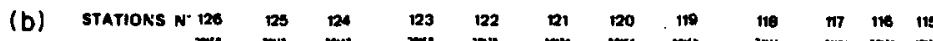

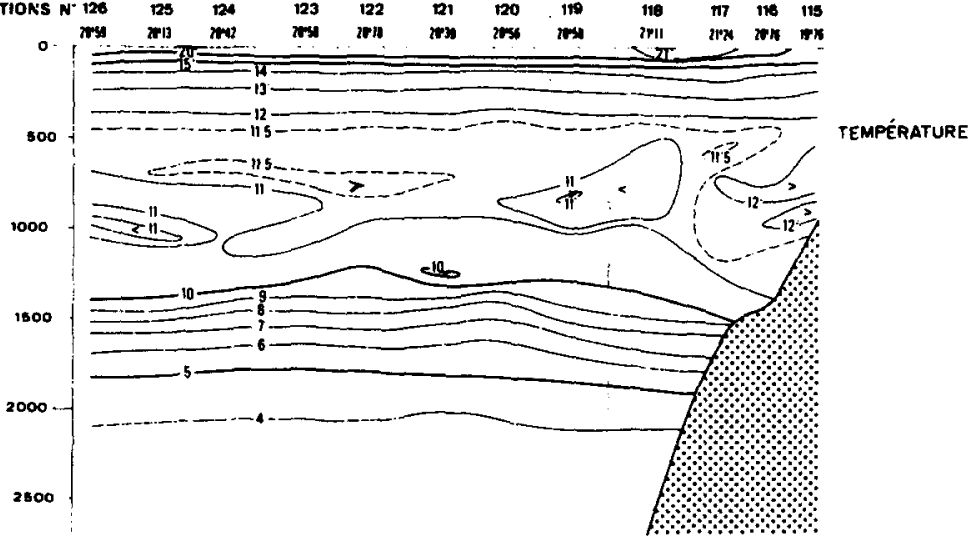

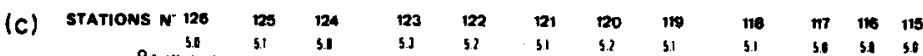

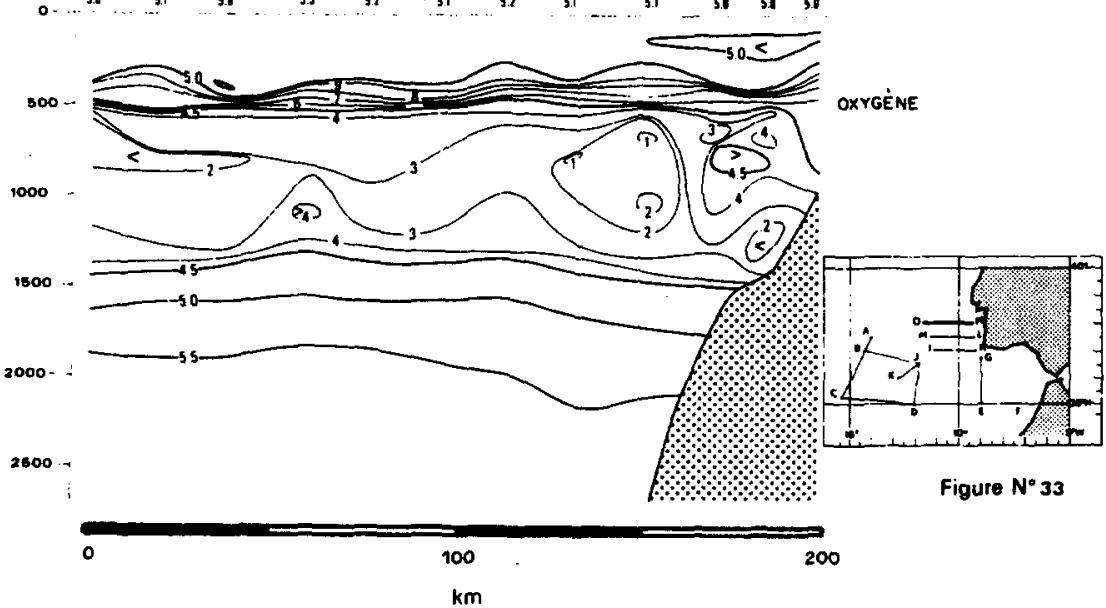

Fig. 4. Reproduction of zonal section F by MADELAIN (1976). This section runs offshore south of the Tejo mouth, Lisbon. It shows different depth levels for the upper and lower Mediterranean Water cores, best described by their temperature (upper) and salinity (lower core) anomalies. Note that the lower core appears to be laterally split by a portion of less saline $(\leq 36.3)$ water.

(a) Temperature $\left({ }^{\circ} \mathrm{C}\right)$, (b) salinity $(\%)$, (c) oxygen $(\mathrm{ml} / \mathrm{l})$. 
our "gateway" section S. In contrast to the upper core we observe a slightly decreased density at the depth of the main core $\sigma_{1}=32.20$ (compared to the initial value near Cape St. Vincent, $\sigma_{1}=32.25$ ).

\section{GEOSTROPHIC CURRENT PROFILES AND TRANSPORTS}

The three quasi-synoptic Meteor CTD sections all running to the continental slope allow us to calculate and compare geostrophic mass transport of the Mediterranean Water undercurrent as it progresses northward. Only stations deeper than $950 \mathrm{~m}$ were considered. The reference layer was close to $2000 \mathrm{dbar}$ or, where shallower, at the bottom. Where possible we integrated vertically between 600 and $1500 \mathrm{dbar}$ which makes our results nearly compatible with KÄsE et al. (1989), although they referenced their level of no motion at $3000 \mathrm{dbar}$.

In Fig. 7 we display four typical geostrophic current profiles from the Mediterranean Water outflow that were calculated from selected station pairs of sections $S, M$ and $N$ (indicated in Figs 2, 3 and 5 by bars at the surface). The most predominant feature in section $S$, which we saw in Fig. $2 b$, is encountered at the western flank of the upper salinity core below 600 dbar where its geostrophic speed profiled $S_{\mathrm{u}}$ exceeds $25 \mathrm{~cm} \mathrm{~s}^{-1}$. Its counterpart $S_{1}$ in the lower (main) salinity core shows a velocity maximum between 1200 and $1300 \mathrm{dbar}$. The northward speed component appears to be only $1 / 3$ of the upper outflow maximum. In section M (Fig. 3) we see the warm, highly salty core layer to be represented by the upper core at $700 \mathrm{dbar}$. The corresponding profile is shown in Fig. 7 . It is not unexpected to find a high amount of similarity between this profile (maximum speed $10 \mathrm{~cm} \mathrm{~s}^{-1}$ ) and the corresponding profile at our "gateway" section $S_{\mathrm{u}}$. The fourth profile is taken from the near-slope part of section N. Although section N (Fig. 5) had shown two discrete stratification cores near the shelf edge-high temperature being more representative of the upper core layer and high salinity for the lower core layer-they both can no longer be distinguished in their dynamical signal. The corresponding profile in Fig. 7 shows a broad maximum range of $O\left(10 \mathrm{~cm} \mathrm{~s}^{-1}\right)$ between 700 and $1200 \mathrm{dbar}$.

Table 1 summarizes geostrophic transports calculated for sections $S, M$ and $N$. The western part of section S, between Gettysburg Bank and Ampère Bank or at least its northwestern component, seems to play a minor role in the total geostrophic transport of Mediterranean Water towards the deep western Iberian and Canary Basins. Disregarding the local circulation around Ampère Bank, no significant transport $(<0.24 \mathrm{~Sv})$ could be found. A banded structure of alternating geostrophic currents indicates that eddy noise has the same magnitude as transport of Mediterranean Water from the assumed point source south of Cape St. Vincent. The total transport east of Gettysburg Bank amounts to $2.03 \mathrm{~Sv}$. This number seems to be small compared to values found in the literature and discussed in the Introduction. However, if we consider the main outflow streams, seen in the hydrography of section S (Fig. 2) separately we find more familiar numbers. At the time of our CTD section S in January 1989 apparently the upper salinity core situated close to the continental rise $(2.73 \mathrm{~Sv})$ transported more than twice as much as the lower core (1.24 Sv).

We do not know the reason for this surprisingly unequal flow distribution, especially since we missed a close-up view southwest of our section $\mathbf{M}$. Possibly a strong outflow event, similar to the one observed by GrünDLINGH (1981), could have accelerated the upper core. One also could speculate that the lower core was observed in a regeneration 
(a)

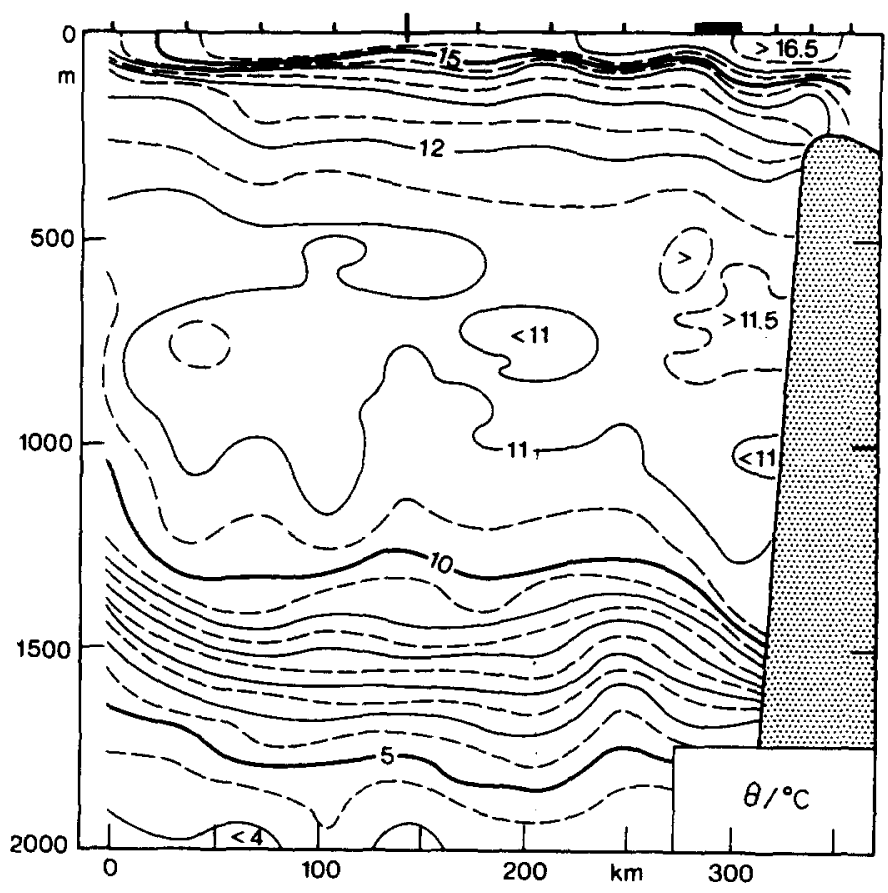

(b)

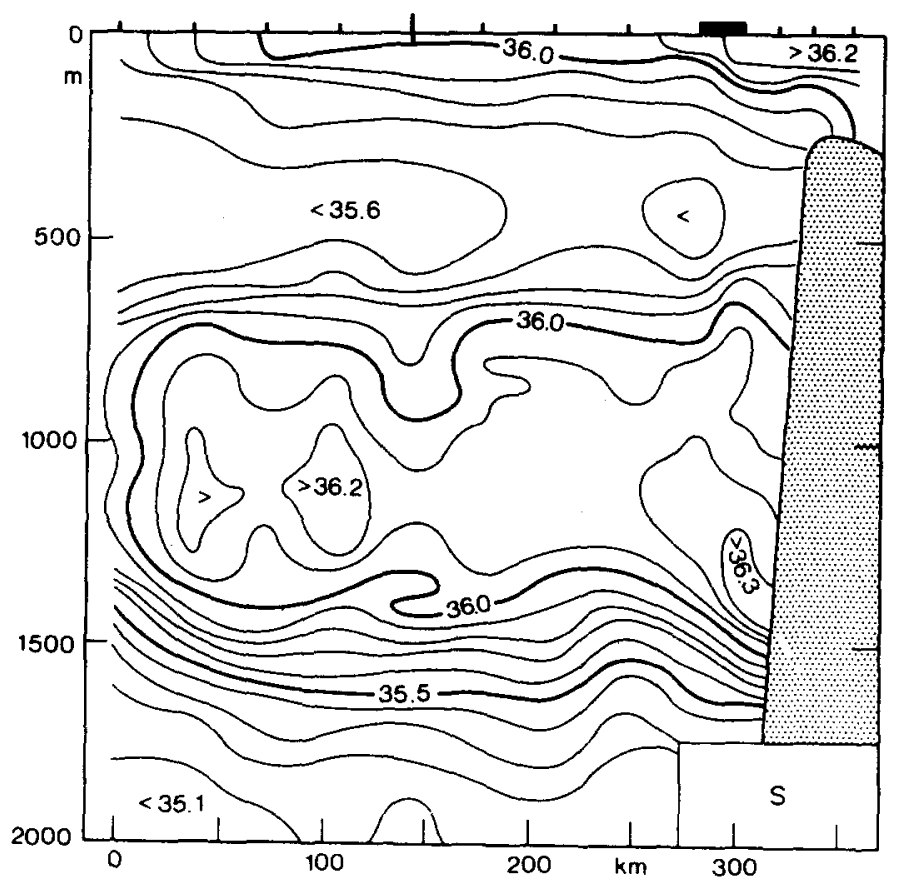




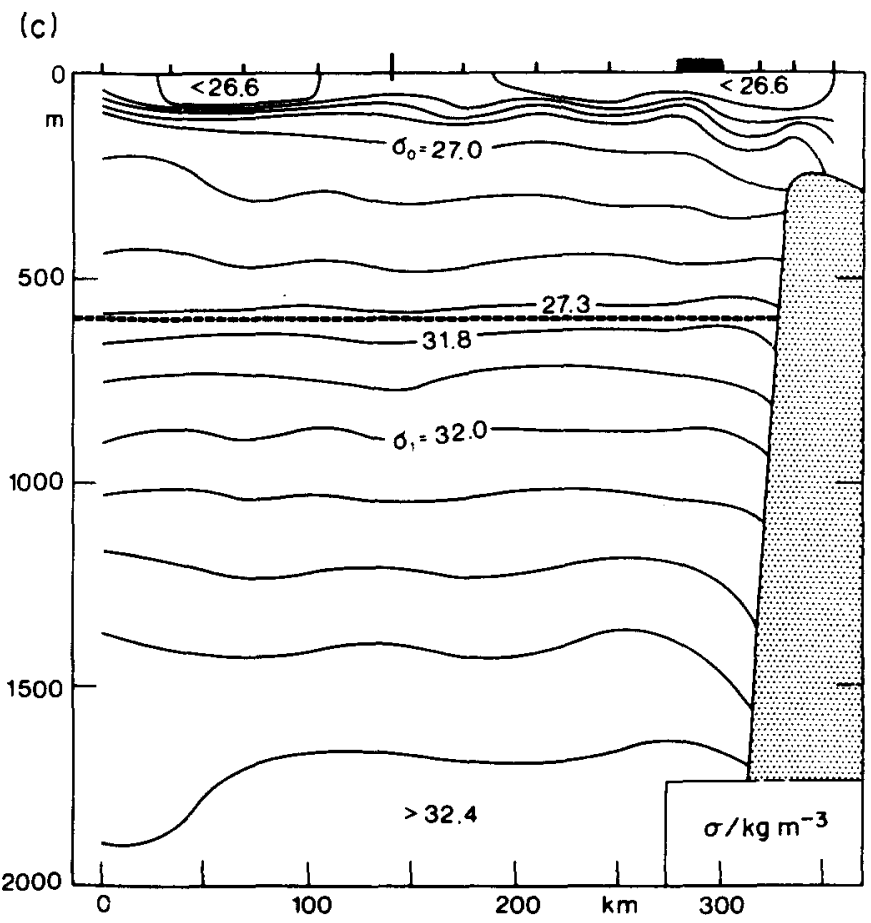

Fig. 5. CTD section N leading south from the southern extend of the Galicia Seamount. From the break point on, it runs southeastward towards the flanks of Tejo Bank. As in previous sections we note the warm saline core layer in the $\mathbf{1 2 5 0}$ dbar range. Further expressions of Mediterranean Water were found at the continental slope where the lower core was observed as deep as $1400 \mathrm{~m}$. The upper core shows a more pronounced temperature signal than the lower core layers do. (a) Potential temperature, (b) salinity, (c) densities $\sigma_{0}$ and $\sigma_{1}$.

Table 1. Northward mass transport between 600 and $1500 \mathrm{dbar}$, including core layer temperatures and salinities, and reference layers. Corresponding sections are displayed in Figs 2, 3 and 5

\begin{tabular}{|c|c|c|c|c|}
\hline \multirow[b]{2}{*}{ Position } & \multirow[b]{2}{*}{$\begin{array}{c}\text { Reference } \\
\text { layer } \\
\text { (dbar) }\end{array}$} & \multicolumn{2}{|c|}{ Core layer } & \multirow[b]{2}{*}{$\begin{array}{c}\text { Northward Mas } \\
\text { Transport } \\
\left(10^{6} \mathrm{~m}^{3} \mathrm{~s}^{-1}\right)\end{array}$} \\
\hline & & $\begin{array}{c}\text { Temp. } \\
\left({ }^{\circ} \mathrm{C}\right)\end{array}$ & $\begin{array}{c}\text { Sal. } \\
\text { (PSU) }\end{array}$ & \\
\hline
\end{tabular}

\section{Section $S$ \\ East of Gettysburg Bank \\ ("Gateway")}

Total, including counter currents

Upper core only

Lower (main)

core only

West of Gettysburg Bank

$\begin{array}{cccc}\begin{array}{c}94-2000 \\ 2000\end{array} & >12.5 & >36.2 & 2.03 \\ 2000 & >11.5 & >36.4 & 1.24 \\ 1828-2000 & >10.5 & >36.2 & 0.24 \\ & <11.0 & & \\ 2000 & >12.0 & >36.1 & 2.92 \\ & & & \\ 2000 & >10.5 & >36.2 & 3.52 \\ & <12.0 & & \end{array}$

\section{Section $\mathrm{M}$}

Upper core only

$<12.0$

Section N

Inner leg only 
(a)

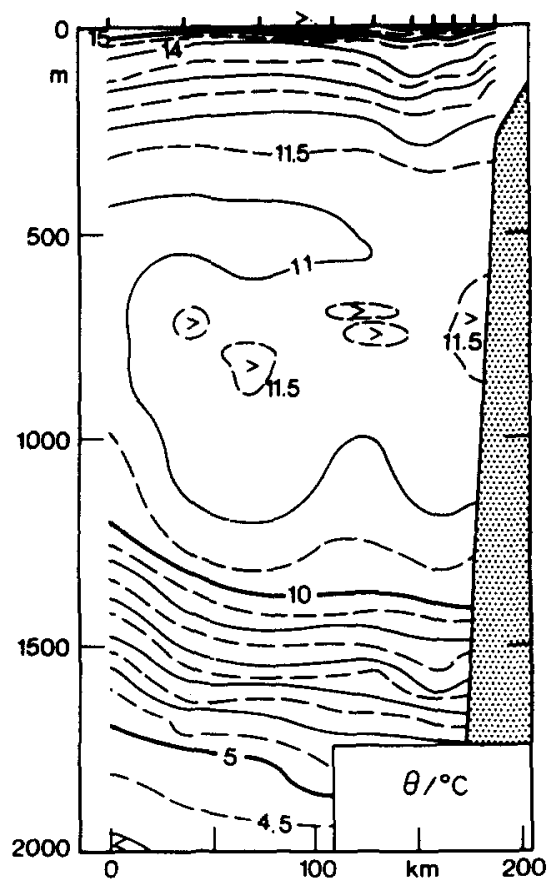

(b)

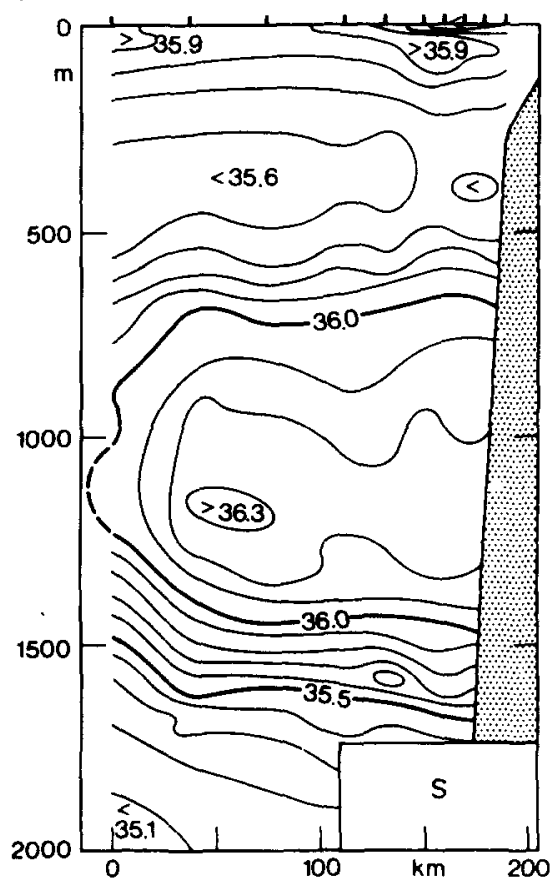

(c)

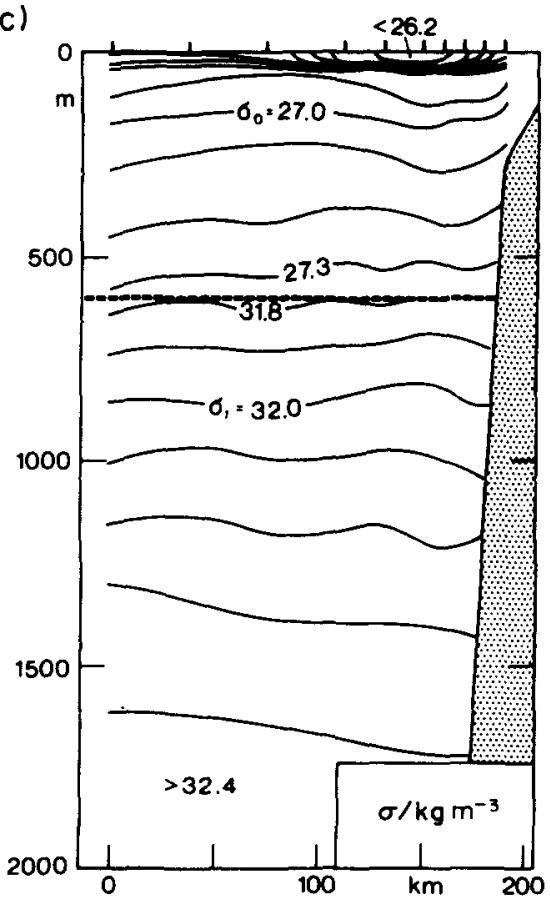

Fig. 6. Section P obtained by F.S. Poseidon during June 1989. As seen in the more southward situated sections, we recognize the upper core in the temperature signal (a) at $\sim 750 \mathrm{dbar}$ in contact with the continental slope. The lower core is documented in salinity (b) at $\sim 1250 \mathrm{dbar}$, Its width exceeds $200 \mathrm{~km}$. Northward flow in the Mediterranean Water level is best reflected by the tilt of the $\sigma_{1}=32.3$-isoline (c). 


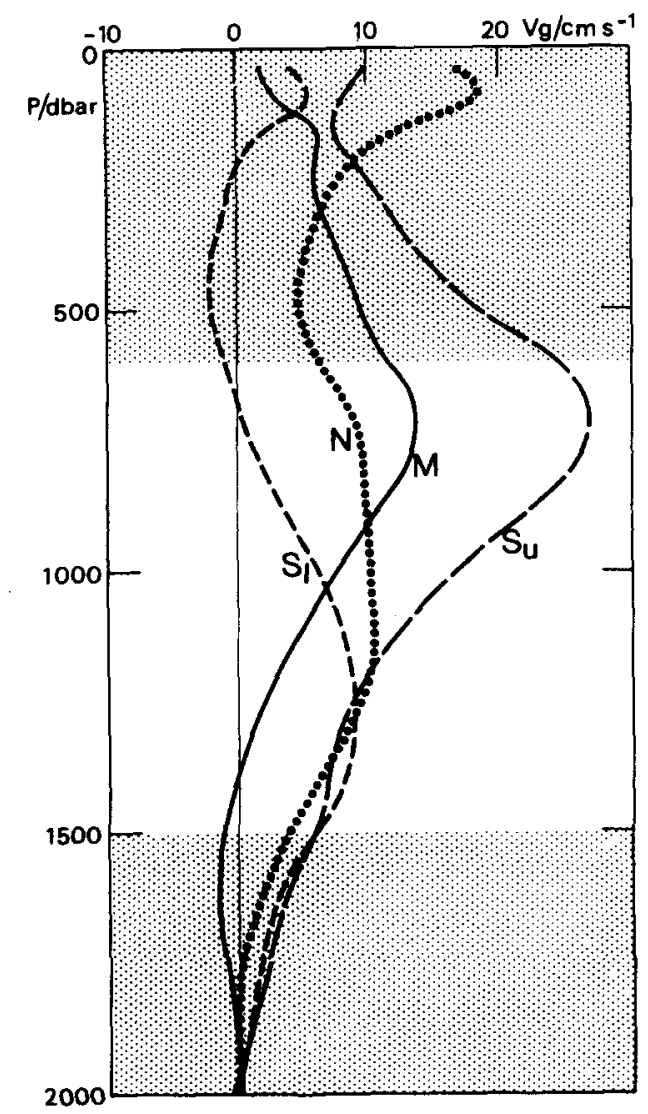

Fig. 7. Selected geostrophic current profiles from synoptic sections $S, M$, and N. All currents are referenced to $2000 \mathrm{dbar}$, the deepest available observation level. Station pairs in Figs 2, 3, and 5 are labeled by bars. Note that in the case of sections $S$ and $M$ the speed maxima coincided with the stratification data, while at section $\mathrm{N}$ we find a broad intermediate maximum in the geostrophic profile. This corresponds to merging cores marked by high temperature and salinity anomalies

(Fig. 5), $S_{1}$ represents the lower (main) core, $S_{\mathrm{u}}$ the upper core at our "gateway" section $\mathrm{S}$.

phase after a Meddy-like feature had been separated slightly before. In any case, a total of approximately $4 \mathrm{~Sv}$ compares favorably with synoptic observations obtained 9 months earlier by KÄSE et al. (1989) who report a "3-4 Sv westward supply southwest of Cape St. Vincent".

On its outbound path along the continental shelf, the upper core passes through in section $\mathrm{M}$ where we calculate a slightly higher number ( $2.92 \mathrm{~Sv}$ ) than at section $\mathrm{S}$. This small difference of $0.19 \mathrm{~Sv}$ could easily be caused by entrainment on the transition between both sections $(\sim 200 \mathrm{~km})$, where the upper core salinity decreased by $>0.2$.

The southeastern extent of section $\mathrm{N}$ gives us a third quasi-synoptic view of the nearslope branch. The volume transport increases again by about $20 \%$, when compared to section M. Both, further entrainment along the flank of Tejo Plateau and a substantial contribution of the lower core have contributed to the total flow rate (3.52 Sv) in this inner leg of section N. A closer inspection of zonal geostrophic transports around the two 

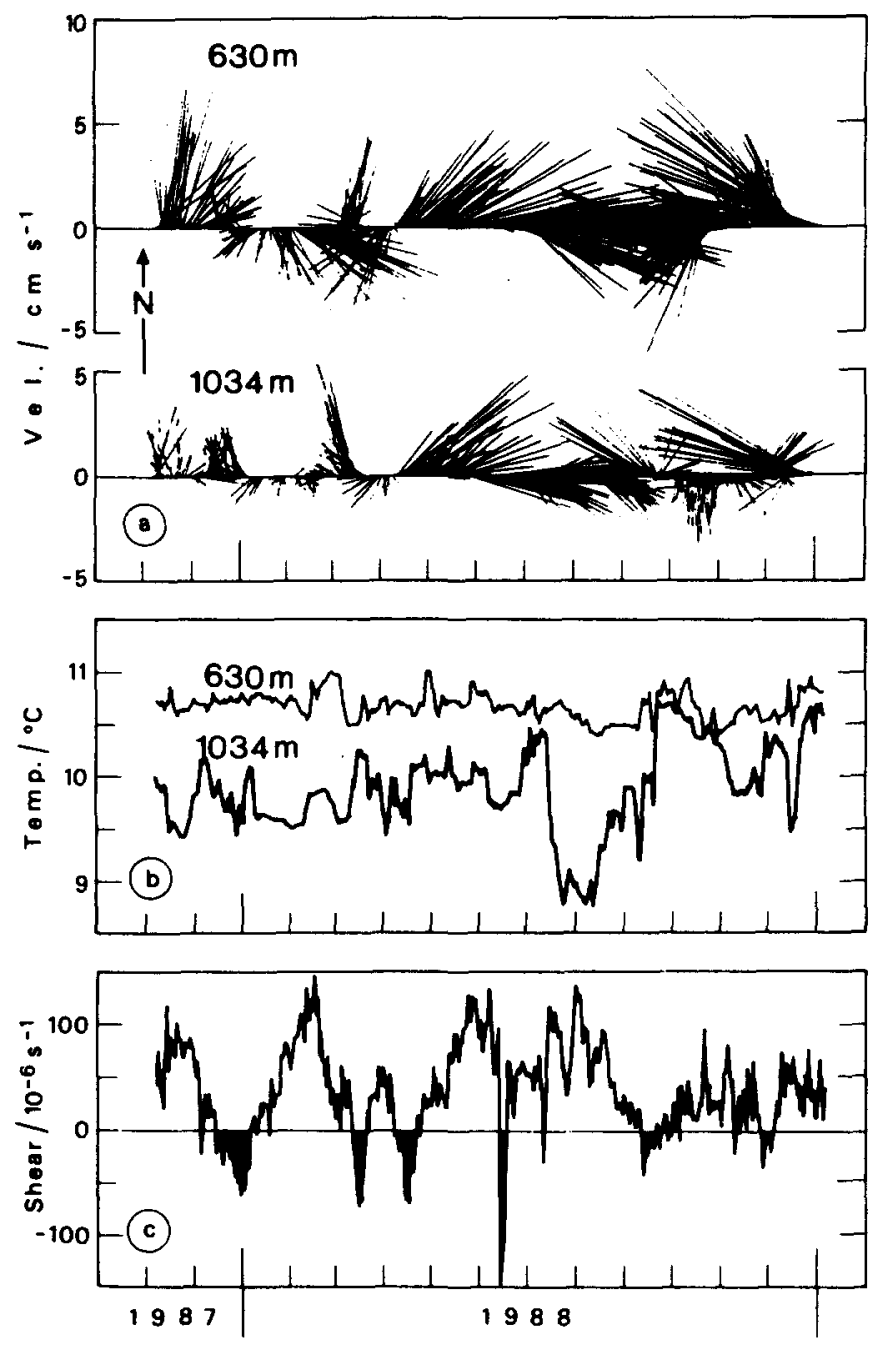

Fig. 8. Records from current meter mooring KIEL311 from the southern Iberian Basin $\left(36^{\circ} \mathrm{N}\right.$, $18^{\circ} \mathrm{W}$ ). The upper portion (a) displays daily averaged vector time series from two levels, 630 and $1034 \mathrm{~m}$, in the Mediterranean Water range. Current pulsations with variable directions dominate the picture. Associated temperature series are shown under (b). Different variances in both temperature series indicate the $1034 \mathrm{~m}$ level to be more active in mixing of water masses of different properties. Curve (c) represents the vertical current shear calculated from both records in (a). Negative values indicate intervals when the lower current meter recorded higher values than the upper instrument.

isolated salinity features at the $1200 \mathrm{dbar}$ level in the north-south leg of section $\mathrm{N}$ shows these cells to be much less energetic than the two cores encountered west of the slope edge. Their maximum geostrophic speed rarely exceeded $3 \mathrm{~cm} \mathrm{~s}^{-1}$, resulting in a rather small transport rate of $>0.3 \mathrm{SV}$. 


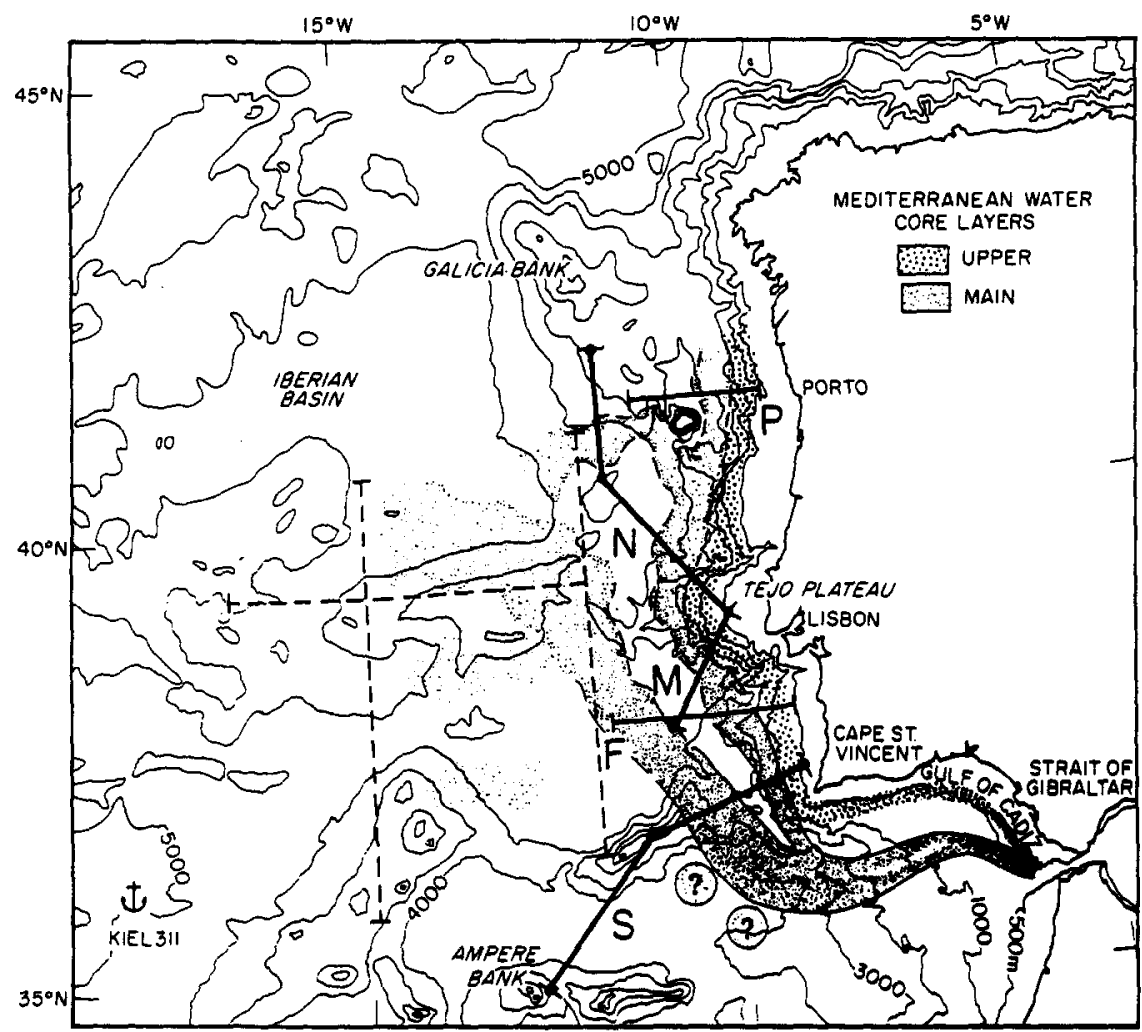

Fig. 9. Spreading pattern of the Mediterranean Water in the eastern North Atlantic. The outflowing Gibraltar Water is preconditioned by mixing in the Gulf of Cadiz. Arriving at Cape St. Vincent it forms two stacked virtual sources while spreading northward. The upper core primarily follows the bottom contour of the Portuguese continental slope. The lower or main core spreads more northwesterly after passing our "gateway" between Cape St. Vincent and the Gettysburg Bank. Further west it forms the background field with irregularly embedded meanders, highly saline pools and Meddies. Meddy formation in the outer Gulf of Cadiz area, indicated by (?), recently was investigated by KENNELLY et al. (1989).

\section{CURRENT METER OBSERVATIONS}

From November 1987 until the Meteor cruise in January 1989, IfM Kiel had a deep-sea mooring at the latitude of Gibraltar, approximately $800 \mathrm{~km}$ west of Cape St. Vincent, i.e. in the southern part of the Iberian Basin (Fig. 1, location KIEL311). This site was chosen to be in the western extent of the climatological tongue of the Mediterranean Water (KäsE and ZENK, 1987) where we could expect temporal variability and thickness variations typical for the background field, as seen in the western part of section $\mathrm{S}$. The sub-surface mooring consisted of three current meters at 630,1034 and $1438 \mathrm{~m}$ depth, and two thermistor chains attached to the lines between the current meters.

A full description of the mooring operation and the retrieved data set can be found in ZENK et al. (1989). Because we obtained no direction record from the lowest instrument, we discuss here only data from the upper and the middle current meters. Their records 


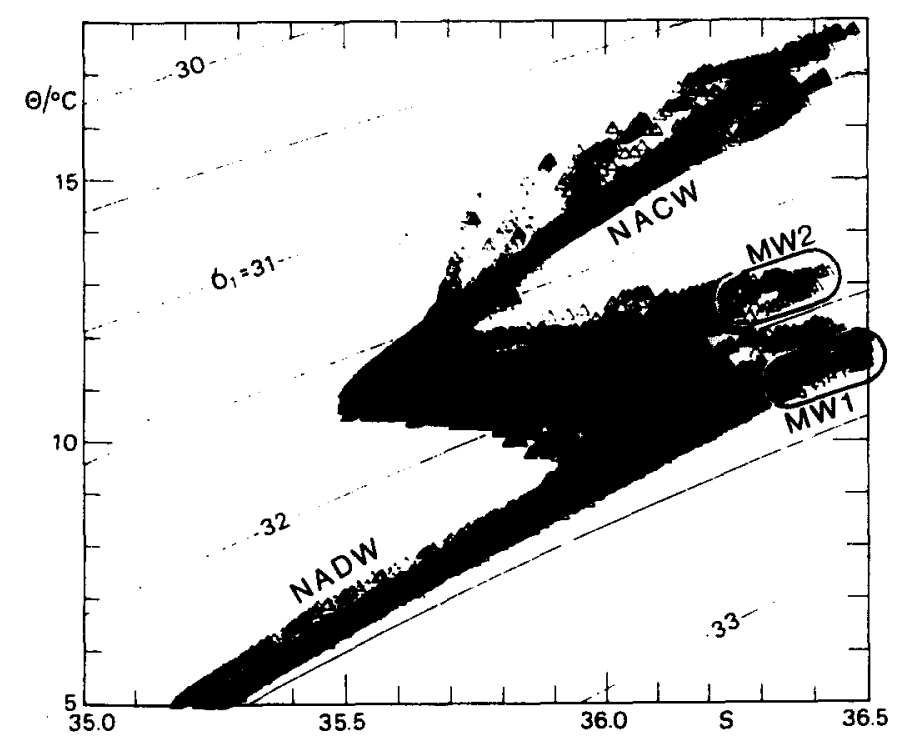

Fig. 10. Potential temperature vs salinity diagram of all CTD stations taken during first leg of Barlavento Expedition. The Mediterranean Water stands out by two peaks (MW1 and MW2), both representing warm and saline cores at different density (and depth) layers. At its upper surface the Mediterranean Water (MW2) entrains North Atlantic Central Water (NACW); its lower side (MW1) mixes with North Atlantic Deep Water (NADW). Density lines are referred to 1000 dbar.

have the potential to be representative for the spreading of the upper and the main cores of the Mediterranean Water tongue as discussed in the previous sections.

In Fig. 8 we represent current vectors (a) with their associated temperatures (b), and scalar shear fluctuations (c) from mooring KIEL311. These time records are dominated by strong current events of variable length and directions. No mean flow can be detected; instead, progressive vector diagrams, not displayed here, show the low frequency motion over 13 months to be divided into three segments. Until May 1988 there is a northeastward tendency with some unsteady meandering. This phase ends with stable eastward current until September, when after further unstable fluctuations the current accelerated again until the end of the record in January 1989. This last segment of our continuous record was the only time when the current direction was in fair agreement with the classical picture of a westward fan-like spreading of the Mediterranean Water tongue (DEFANT, 1955).

A strong tendency for high vertical coherence at the two observational levels, 630 and $1034 \mathrm{~m}$, can be seen in the time series (Fig. 8a). Vector averaged currents at the higher level are about $50 \%$ stronger than those at the intermediate level. Temperature variances at $1034 \mathrm{~m}\left(0.18^{\circ} \mathrm{C}^{2}\right)$, however, tend to be one order higher than above. Repeated changes in sign are observed in the shear time series in Fig. 8c. Generally they seem to be correlated with significant changes in the temperature records (Fig. 8b). The much lower temperature variance $\left(0.02^{\circ} \mathrm{C}^{2}\right)$ encountered at the $630 \mathrm{~m}$ level must be caused by a decrease of activity in the upper core layer of the Mediterranean Water. In addition, this shallower part of the outflow tongue is often more confined to near-slope regions off the continent. Only occasional thermal expressions of the upper maximum, seen in the hydrographic stratification, can be found in the shallower current meter record. 


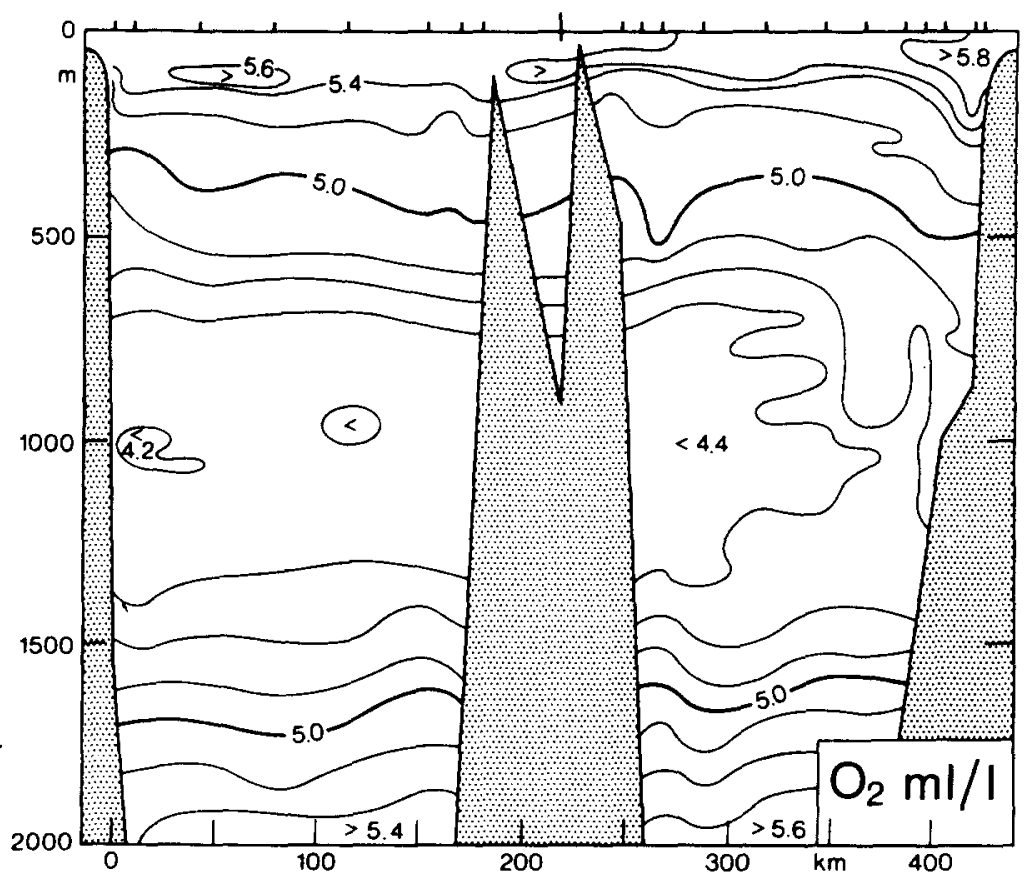

Fig. 11. Oxygen distribution at our "gateway" (section S) of the Mediterranean outflow. Calibration coefficients used were extrapolated from the following cruise legs causing limited absolute accuracy of $\mathrm{O}_{2}$ distribution. However, the pattern shows a relatively high $\mathrm{O}_{2}$ signal (>4.6 ml/1) at the level of the upper core (750 dbar). It is formed by mixing of Gibraltar Water and North Atlantic Central Water, which is not inconsistent with Madelain's (1976) observation reproduced in Fig. $4 \mathrm{c}$. The background field at 1250 dbar contains less oxygen $\left(4.2<\mathrm{O}_{2}<4.4 \mathrm{ml} / \mathrm{l}\right)$.

We interpret these deep intermittent speed maxima associated with abrupt temperature fluctuations as expressions of separated warmer mesoscale features of Mediterranean Water, possibly Meddies. They drift around within the background field and pass by the mooring location. This scenario was first described by ARMI and ZENK (1984) for the KIEL276 mooring centered at the deep Canary Basin $\left(33^{\circ} \mathrm{N}, 22^{\circ} \mathrm{W}\right)$.

\section{DISCUSSION AND SUMMARY}

The Mediterranean Water undercurrent leaving the Strait of Gibraltar undergoes a preconditioning mixing process in the Gulf of Cadiz. Part of the outflow follows the northern slope of the Gulf at approximately $600 \mathrm{~m}$ depth, mixing with the overlying oxygenated North Atlantic Central Water. A second outflow branch, generally transporting substantially larger volumes than the slope branch, is guided by various channels down to $1200 \mathrm{~m}$, where is starts spreading horizontally (ZENK, 1975a).

As both branches from the Gulf of Cadiz flow through a broad "gateway" between Cape St. Vincent and the shallow Gettysburg Bank (Fig. 9), they retain their own characteristics in temperature and salinity (Fig. 10). The upper core shows a stronger tendency to follow closely bottom contours along the Portuguese continental slope at approximately $750 \mathrm{~m}$. It is best characterized by high temperatures and slightly higher oxygen content (Figs $4 \mathrm{c}$ and 11) at a density level of $\sigma_{1}=31.85$. The lower core, clearly separated in the horizontal and 


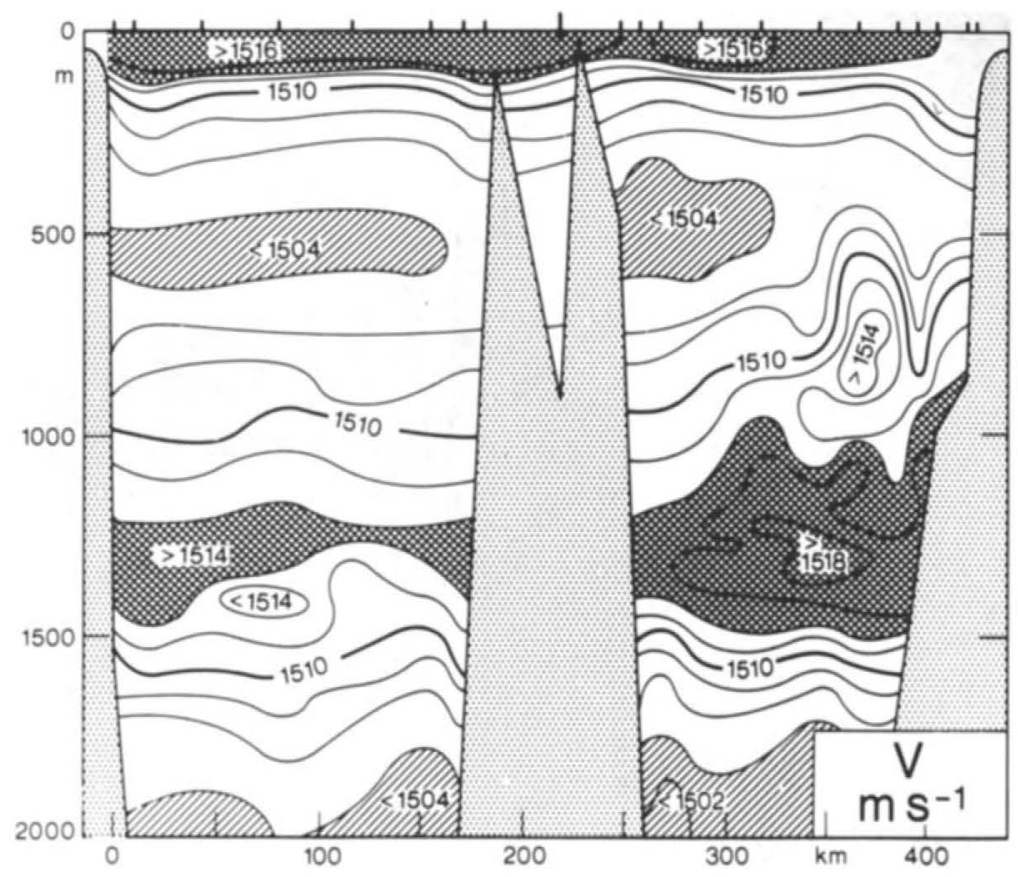

Fig. 12. Distribution of velocity of sound at section S calculated from CTD observations. Note that the classical SOFAR channel (sound velocity minimum) is split by a maximum at the lower core of the Mediterranean outflow.

the vertical, was found at approximately $1250 \mathrm{~m}$. This outflow branch is identical with the classical core layer. In the Iberian Basin it can be best described by salinity on a $\sigma_{1}=32.15$-surface. The main (lower) core splits just north of the "gateway". Most of the core water appears to meander west and northwestward, under the influence of lateral instability processes ( $c f$. KÄsE et al., 1989). A smaller portion seems to follow the deep continental slope as does the upper core.

These observations show two well-defined sources for the Mediterranean Water: an upper and a lower core. The existence of these two dominant sources and the complex spreading pattern with meanders and Meddies suggest future measurement by Langrangian techniques as opposed to traditional Eulerian views presented here. Since such experiments are presently underway (ZENK, 1990) or in the planning stages, we mention a relevant curiosity in the hydrography: analysis of RAFOS foat trajectories ( $c f$. RossBY et $a l ., 1986)$ requires the knowledge of the SOFAR sound channel. Figure 12 shows the distribution of sound velocity along section $S$. There are two minima at about $500 \mathrm{dbar}$ and $2000 \mathrm{dbar}$. This suggests that seeding of floats in the main core should be at approximately $1100 \mathrm{dbar}$, i.e. above the sound velocity maximum.

Acknowledgements-This work has been made possible by a grant of Deutsche Forschungsgemeinschaft (SFB 133). The help of $\mathbf{B}$. Klein, and $\mathbf{M}$. Vaniczek as well as the excellent cooperation of Captain $H$. Bruns and his Meteor crew are gratefully acknowledged. I. Ambar and Deep-Sea Research reviewers provided us with valuable suggestions on an earlier version of the manuscript. The Germanic spelling of L.A.'s given name is intentional, since this was a German project; funds for his participation were provided by the National Science Foundation. 


\section{REFERENCES}

AMBAR I. and M. R. Howe (1979a) Observations of the Mediterranean outflow. I. Mixing in the Mediterranean outflow. Deep-Sea Research, 26, 535-554.

AMBAR I. and M. R. HowE (1979b) Observations of the Mediterranean outflow. II. The deep circulation in the vicinity of the Gulf of Cadiz. Deep-Sea Research, 26, 555-568.

ARMI L. and W. ZENK (1984) Large lenses of highly saline Mediterranean water. Journal of Physical Oceanography, 14, 1560-1576.

Armi L., D. Hebert, N. OAkey, J. F. Price, P. L. Richardson, H. T. Rossby and B. Ruddick (1989) Two years in the life of a Mediterranean salt lens. Journal of Physical Oceanography, 19, 354-370.

BUCHAN A. (1895) Report on oceanic circulation, based on the observations made on board HMS "Challenger", and other observations. Report on the Voyage of Challenger, Summary of the scientific results, Vol. 2.

Defant A. (1955) Die Ausbreitung des Mittelmeerwassers im Nordatlantischen Ozean, Papers of Marine Biological Oceanography, 465-470.

GRÜNDLINGH M. L. (1981) On the observation of a solitary event in the Mediterranean outflow west of Gibraltar. "Meteor" Forsch.-Ergebn., A/B, 23, 15-46.

Howe M. R. (1982) The Mediterranean water outflow in the Gulf of Cadiz. Oceanographic Marine Biological Annual Review, 20, 37-64.

Howe M. R. (1984) Current and hydrographical measurements in the Mediterranean undercurrent near Cape St. Vincent. Oceanologica Acta, 7, 163-168.

KÄSE R. H. and W. ZENK (1987) Reconstructed Mediterranean salt lens trajectories. Journal of Physical Oceanography, 17, 158-163.

Käse R. H., A. BeCKMANN and H. H. HinrichSEN (1989) Observational evidences of salt lens formation in the Iberian Basin. Journal of Geophysical Research, 94, C4, 4905-4912.

Kenelly M. A., M. D. Prater and T. B. Sandford (1989) XBT and XSV data from the Gulf of Cadiz Expedition: R.V. Oceanus Cruise 202, Technical Report 8920, Applied Physics Laboratory, University of Washington, Seattle, $30 \mathrm{pp}$.

MADELAIN F. (1970) Influence de la topographie du fond sur l'écoulement méditerranéen entre le Détroit de Gibraitar et le Cap Saint-Vincent. Cahiers Océanographiques, 22, 43-61.

MAdelaIN F. (1976) Circulation des eaux d'origine méditerranéene au niveau du Cap St-Vincent, Hydrologie et courants de densité. Rapports scientifiques techniques, CNEXO, 24, 74 pp.

OchoA J. L. and N. A. BraY (1990) Water mass exchange in the Gulf of Cadiz. Deep-Sea Research (in press).

Rossiy T., D. Dorson and J. Fontaine (1986) The RAFOS system. Journal of Atmospheric and Oceanic Technology, 3, 672-679.

Siedler G., W. ZeNK and W. J. Emery (1985) Strong-current events related to a subtropical front in the Northeast Atlantic. Journal of Physical Oceanography, 15, 885-897.

Wüst G. (1936) Schichtung und Zirkulation des Atlantischen Ozeans, Die Stratosphäre, Wiss. Ergebn. Dtsch. Atl. Exped., Meteor 1925-1927, 6(1), $180 \mathrm{pp}$.

ZENK W. (1975a) On the Mediterranean outflow west of Gibraltar. "Meteor" Forsch.-Ergebn., A, 16, 23-34.

ZENK W. (1975b) On the origin of the intermediate double-maxima in the T/S profiles from the North Atlantic. "Meteor" Forsch.-Ergebn., A, 16, 35-43.

ZeNK W. (1990) Project "German RAFOS", ARGOS Newsletter, 39, 13-17.

Zenk W. and T. J. MüLler (1988) Seven-year current meter record in the eastern North Atlantic. Deep-Sea Research, 35, 1259-1268.

Zenk W., T. J. Müller and G. Wefer (1989) BARLAVENTO-Expedition, Reise Nr. 9, 29. Dez. 1988-17. März 1989. Meteor-Berichte, Universität Hamburg, 89-2, 238 pp.

Zenk W., B. Klein and M. Schröder (1990) Cape Verde Frontal Zone. Deep-Sea Research (in press). 